\title{
EFEK BAHAN FILLER LOKAL TERHADAP KUALITAS FISIK DAN KIMIA BAKSO AYAM PETELUR AFKIR
}

\author{
Lija Numria Nullah ${ }^{1}$, Harapin Hafid ${ }^{2}$, Amiluddin Indi ${ }^{2}$ \\ ${ }^{1)}$ Alumnus Fakultas Peternakan Universitas Halu Oleo \\ ${ }^{2)}$ Fakultas Peternakan, Universitas Halu Oleo. \\ Kampus Hijau, H.E.A. Mokodompit, Kendari,93232 \\ e-mail :harapinhafid@yahoo.co.id
}

\begin{abstract}
Abstrak
Penelitian ini bertujuan untuk menghasilkan produk olahan daging ayam petelur afkir yaitu bakso dengan nilai gizi sesuai dengan standar nasional produk olahan dan untuk mengevaluasi daya suka konsumen terhadap bakso ayam petelur afkir yang menggunakan filler lokal Sulawesi Tenggara melalui uji organoleptik. Penelitian ini menggunakan Rancangan Acak Lengkap, 3 perlakuan dan 4 ulangan. Perlakuan yang dilakukan adalah P1= daging ayam petelur afkir $60 \%$ dan tepung sagu $25 \%, \mathrm{P} 2=$ daging ayam petelur afkir $60 \%$ dan tepung ubi kayu $25 \%$, dan daging ayam petelur afkir $60 \%$ dan tepung talas $25 \%$. Variabel penelitian meliputi uji kualitas fisik (susut masak dan $\mathrm{pH}$ ), uji organoleptik (warna, aroma, tekstur, kekenyalan, dan rasa), dan uji kimia (kadar air, protein, lemak, dan abu). Hasil penelitian menunjukkan bahwa penambahan bahan filler lokal tidak berpengaruh nyata $(p>0,05)$ terhadap susut masak, kadar air, lemak, tekstur, kekenyalan, dan rasa bakso akan tetapi berpengaruh nyata $(p<0,05)$ terhadap $\mathrm{pH}$ bakso, kadar protein, abu dan warna bakso. Disimpulkan bahwa perlakuan terbaik didapat pada penambahan tepung sagu dan ubi kayu yang banyak disukai panelis.
\end{abstract}

Kata kunci: Bakso Ayam, Filler Lokal, Kualitas Fisik, Organoleptik dan Kimia

\begin{abstract}
A study to produce processed meat products laying hens culled with nutritional value in accordance with national standards and to evaluate the processed products like consumer power to salvage the laying chicken meatballs using local filler Southeast Sulawesi through organoleptic test This study used a completely randomized design, 3 treatments and 4 replications. The treatment is done is $\mathrm{P} 1=$ meat laying hens rejects $60 \%$ and $25 \%$ corn starch, $\mathrm{P} 2=$ meat laying hens rejects $60 \%$ and $25 \%$ cassava flour, and meat laying hens rejects $60 \%$ and $25 \%$ of taro flour. The research variables include physical quality test (shrinkage cooking and $\mathrm{pH}$ ), organoleptic (color, aroma, texture, elasticity, and taste), and chemical tests (moisture, protein, fat, and ash). The results showed that the addition of filler materials locally not significant $(p>0.05)$ to the cooking shrinkage, moisture, fat, texture, elasticity, and flavor meatballs but significant $(\mathrm{p}<0.05)$ against $\mathrm{pH}$ meatballs, levels protein, ash and color meatballs. It was concluded that the best treatment obtained on addition of corn starch and cassava are much preferred the panelists.
\end{abstract}

Keywords: Chicken Meatballs, Local Filler, Quality Physical and Chemical

PENDAHULUAN

Pemenuhan kebutuhan gizi masyarakat dapat diperoleh dari hasil hewani yang digunakan sebagai sumber protein seperti daging ayam pedaging sebagai sumber protein yang banyak diminati oleh masyarakat, diantaranya ayam broiler, ayam kampung, dan ayam petelur afkir. Ayam petelur afkir umumnya produksi telurnya menurun 
pada umur 24 bulan diumur tersebut ayam petelur diafkir dan dimanfaatkan dagingnya sebagai daging potong. Karena dagingnya yang alot dibandingkan dengan ayam pedaging sehingga kurang di sukai konsumen.

Upaya pemanfaatan atau peningkatan daya guna daging ayam petelur afkir tersebut perlu dilakukan mengolah menjadi suatu produk yang lebih berkualitas dan disukai konsumen. Untuk mengubah ketidaksukaan pada daging ayam petelur afkir maka perlu dibuat kombinasi dan variasi pengolahan diantaranya yaitu dibuat bakso. Bakso merupakan produk olahan yang sangat berpotensi di pasaran Indonesia (Buckle et al,1987)

Bakso dapat dibuat dari berbagai jenis daging misalnya daging sapi, kerbau, daging ayam dan daging ikan. Sebelumnya masyarakat hanya mengenal bakso yang terbuat dari daging sapi saja, tetapi daging ayam juga sudah banyak diolah menjadi bakso ayam. Daging ayam yang digunakan adalah daging ayam petelur afkir yang memiliki nilai ekonomis lebh murah. Bakso ayam dibuat dengan bahan utama daging ayam lalu ditambahkan bumbu-bumbu tertentu. Dalam pembuatan bakso biasanya ditambahkan tepung misalnya tepung tapioka (Almasuryani, 2009).

Bakso dibuat dari campuran daging tidak kurang dari $50 \%$ dan pati atau tepung serealia, dengan atau tanpa bahan tambahan makanan yang diizinkan. Bakso biasanya disajikan bersama mie atau bihun, sayuran, dan kuah. Proses pembuatan bakso pada umumnya menggunakan tepung tapioka. Adapun penambahan tepung sebagai filler bakso berguna untuk memperbaiki tekstur, meningkatkan daya ikat air, menurunkan penyusutan akibat pemasakan dan meningkatkan elastisitas produk. Dalam rangka penganekaragaman pangan, fungsi ini bisa digantikan dengan tepung lain seperti tepung sagu, ubi kayu, dan talas.

\section{MATERI DAN METODE}

Penelitian ini dilaksanakan di Laboratorium Nutrisi dan Teknologi Pakan Jurusan Peternakan Fakultas Peternakan untuk persiapan bahan tepung, pembuatan bakso dan uji organoleptik. Sedangkan uji kualitas fisik dan kimia bakso dilaksanakan di Laboratorium Kimia Forensik Jurusan Kimia Fakultas Matematika dan Ilmu Pengetahuan Alam Universitas Halu Oleo. Penelitian ini dilaksanakan Desember 2014 sampai Januari 2015.

Alat yang di gunakan dalam penelitian ini adalah penggiling daging/blender, timbangan electrik, sendok, wadah-wadah plastik, pisau, talenan, piring, garpu, gelas, kertas tisu, pisau, kertas kuisioner dan alat tulis. Analisis komposisi kimia peralatan yang digunakan terdiri atas oven, tanur, cawan porselen, gegep, talang, labu kjehdahl, labu erlenmeyer, alat titrasi dan destilasi, kondensor, kertas saring, sintered glas dan desikator. Bahan utama yang di gunakan dalam penelitian ini adalah daging ayam petelur afkir umur 24 bulan dan bahan pengisinya (filler) adalah tepung sagu, ubi kayu, dan talas serta bahan-bahan lain untuk masing-masing perlakuan yaitu es batu, garam, gula, lada, dan bawang putih. Komposisi bahan bakso. Komposisi bahan bakso dalam penelitian ini adalah, daging ayam petelur afkir $60 \%$, tepung/filler $25 \%$, es batu $10 \%$, garam dapur $2,5 \%$, dan bumbubumbu 2,5\%. Bahan yang digunakan untuk analisis terdiri atas aquades, air panas, air bersih, $\mathrm{H}_{2} \mathrm{SO}_{4}$ pekat, $\mathrm{H}_{2} \mathrm{SO}_{4} 0,3$ 
$\mathrm{N}, \mathrm{CuSO}_{4} \mathrm{~K}_{2}+$ selen, $\mathrm{NaOH} 1,5 \mathrm{~N}, \mathrm{HCl}$ $0,1 \mathrm{~N}$, pelarut heksan, asam sulfat $0,3 \mathrm{~N}$ dan alkohol 95\%. Metode yang dilakukan adalah alat dan bahan di cuci terlebih dahulu setelah itu daging di giling menggunakan alat penggiling lalu di giling kembali yang ditambahkan es batu dan bumu-bumbu setelah itu adonan ditambahkan filler dan diaduk hingga homongen stelah itu adonan di bentuk bulat-bulat sesuai keinginan dan di masukkan ke dalam air panas $70^{\circ} \mathrm{C}$ selama \pm 15 menit, setelah bakso terapung bertanda bakso sudah masak, di tiriskan dan siap di uji lanjut. Rancangan penelitian yang digunakan adalah Rancangan Acak Lengkap dengan 3 perlakuan dan 4 ulangan, perlakuan adalah bahan filler lokal $(\mathrm{P})$, terdiri dari : P1 =Tepung Sagu, P2= Tepung Ubi Kay, P3 = Tepung Talas. Apabila hasil yang di peroleh berpengaruh nyata maka akan dilakukan uji lanjut dengan menggunakan uji Beda Nyata Jujur (BNJ) (Steel \& Torrie, 1993).

\section{HASIL DAN PEMBAHASAN}

\section{A. Kualitas Fisik Bakso}

Kualitas fisik bakso daging ayam petelur afkir menggunakan filler lokal pada Tabel 1 .

Tabel 1. Kualitas Fisik Bakso Ayam Petelur Afkir Menggunakan Filler Lokal yang Berbeda

\begin{tabular}{lccc}
\hline \multirow{2}{*}{ Peubah } & \multicolumn{3}{c}{ Bahan Filler Lokal } \\
\cline { 2 - 4 } & $\begin{array}{c}\text { P1 } \\
\text { (Tepun }\end{array}$ & $\begin{array}{c}\text { P2 } \\
\text { (Tepung }\end{array}$ & $\begin{array}{c}\text { P3 } \\
\text { (Tepung }\end{array}$ \\
& g Sagu) & Ubi kayu) & Talas) \\
\hline Susut Masak(\%) & 9,5 & 9 & 9 \\
pH & $6,40^{\mathrm{a}}$ & $6,20^{\mathrm{b}}$ & $6,54^{\mathrm{c}}$ \\
\hline
\end{tabular}

Keterangan: Superskrip berbeda pada baris yang sama menunjukkan berbeda nyata

Susut Masak

Berdasarkan analisis sidik ragam menunjukkan bahwa penggunakan filler lokal yang berbeda memberikan pengaruh yang tidak nyata $(\mathrm{p}>0.05)$ terhadap nilai susut masak. Nilai rataan susut masak bakso ayam petelur afkir menggunakan filler lokal yang berbeda berkisar antara $9 \%$. Pemberian tepung filler $25 \%$ mampu memberikan respon terhadap rendahnya nilai susut masak. Hal ini menunjukkan bahwa pemberian tepung sagu, tepung ubi jalar, dan tepung talas menyebabkan rendahnya nilai susut masak. Hasil yang diperoleh pada penelitian ini lebih tinggi dibandingkan dengan hasil penelitian Rahmawaty. et al (2006) yang menggunakan daging kambing dengan filler tepung tapioka, maizena, tepung terigu dan tepung sagu menghasilkan susut masak pada kisaran 6,86\%.

Rendahnya nilai susut masak dengan penambahan tepung terigu dan sagu menyebabkan besarnya viskositas pati pada tepung tersebut yang diakibatkan tingginya kandungan amilopektin, yang di mana pati dapat menekan air lebih banyak selama proses pemasakan. Hal ini sejalan dengan pernyataan Tiven, (2007) bahwa amilopektin dapat mengikat air dengan membentuk ikatan hidrogen sehingga menahan keluarnya air.

$\mathbf{P h}$

$\mathrm{pH}$ merupakan konsentrasi ion hidrogen yang berdisosiasi dalam larutan. $\mathrm{pH}$ tidak mengukur keasaman seperti titrasi Idris, (2003). Tabel 1 menunjukkan bahwa nilai rataan $\mathrm{pH}$ bakso ayam petelur afkir menggunakan filler lokal memberikan pengaruh yang sangat nyata $(p<0.01)$ yang kisarannya 6,38. Demikian halnya dengan penelitian Dewi, et al (2011) menggunakan suptitusi tepung tapioka dengan pati biji nangka pada tahap 25\% dengan kisaran 6,53. 
perbedaan ini menunjukkan kandungan pati dalam tepung tapioka dan biji nangka lebih baik dalam menurunkan $\mathrm{pH}$ bakso. Nilai $\mathrm{pH}$ dalam penelitian ini sesuai dengan SNI yaitu 6 sampai 7 hal ini berarti bahwa nilai $\mathrm{pH}$ dalam penelitian ini masih memenuhi batasan $\mathrm{pH}$ menurut Standarisasi Nasional Indonesia 01-3818 tahun 1995. Analisis lebih lanjut menggunakan uji BNJ menunjukkan bahwa P1 menggunakan tepung sagu berbeda nyata terhadap P2 menggunakan tepung ubi kayu dan P3 menggunakan tepung talas. Perlakuan P2 menggunakan tepung ubi kayu berbeda nyata dengan perlakuan P3 menggunakan tepung talas.

Nilai pH pada perlakuan P2 menggunakan tepung ubi kayu mengakibatkan perubahan nilai $\mathrm{pH}$ pada bakso. Menurut Kusnandar (2010) kandungan amilosa pada pati cenderung menurukan $\mathrm{pH}$ karena enzim amilase akan memecah amilosa menjadi maltosa. Maltosa terpecah oleh enzim maltase menjadi glukosa dengan gugus aldehid. Gugus aldehid teroksidasi oleh udara (O2) dan berubah menjadi asam karboksilat. Asam karboksilat ini yang akan menurunkan nilai $\mathrm{pH}$.
Komposisi kimia bakso ayam petelur afkir menggunakan filler lokal yang berbeda dapat dilihat pada Tabel 2 .

\section{Kadar Air}

Hasil analisis kadar air pada bakso ayam petelur afkir menggunakan filler lokal yang berbeda memberikan pengaruh yang tidak nyata $(p>0.05)$ terhadap nilai kadar air bakso petelur afkir menggunakan filler lokal yang berbeda. Dari hasil pengukuran kadar air bakso ayam petelur afkir yang tercantum pada Tabel 3 menunjukkan bahwa nilai rataan antara 69,86\%. Kadar air hasil penelitian lebih tinggi dibanding penelitian Rahmawaty (2006) yang menggunakan tepung tapioka, maizena dan tepung sagu berkisar antar 54,67\%. Namun menurut Standarisasi Nasional Indonesia $70 \%$ memenuhi batasan kadar bakso ayam. Jadi kadar air dalam penelitian ini masih memenuhi batasan kadar air SNI.

\section{Kadar Protein}

Hasil analisis kadar protein pada bakso ayam petelur afkir menggunakan filler lokal yang berbeda memberikan pengaruh yang nyata $(p<0.05)$ terhadap nilai protein bakso petelur afkir menggunakan filler lokal yang berbeda.

\section{B. Komposisi Kimia Bakso}

Tabel 2. Komposisi Kimia Bakso Ayam Petelur afkir Menggunakan Filler Lokal yang Berbeda

\begin{tabular}{lccc}
\hline \multirow{2}{*}{ Peubah } & \multicolumn{3}{c}{ Bahan Filler Lokal } \\
\cline { 2 - 4 } & P1 & P2 & P3 \\
& (Tepung Sagu) & (Tepung Ubi kayu) & (Tepung Talas) \\
\hline Kadar Air (\%) & 70,55 & 69,86 & 70,56 \\
Kadar Protein (\%) & $9,22^{\mathrm{a}}$ & $9,46^{\mathrm{b}}$ & $9,65^{\mathrm{ab}}$ \\
Kadar Lemak (\%) & 2,69 & 2,55 & 2,54 \\
Kadar Abu (\%) & $3,41^{\mathrm{a}}$ & $3,24^{\mathrm{b}}$ & $3,6^{\mathrm{c}}$ \\
\hline
\end{tabular}

Keterangan: Superskrip berbeda pada baris yang sama menunjukkan berbeda nyata $(p<0,05)$. 
Analisis lebih lanjut menggunakan uji BNJ menunjukkan bahwa perlakuan P1 menggunakan tepung sagu berbeda nyata terhadap P2 menggunakan tepung ubi kayu dan P3 menggunakan tepung talas.

Dari hasil pengukuran protein bakso ayam petelur afkir yang tercantum pada Tabel 3 menunjukkan bahwa nilai rataan protein bakso ayam petelur afkir menggunakan filler lokal yang berbeda berkisar antara 9,4\%. Nilai protein pada penelitian ini lebih tinggi bila dibanding dengan penelitian Prastya. et al, (2013) dengan suptitusi tepung tapioka dengan tepung sukun berkisar antara 8,5\%. Nilai protein bakso menurut SNI yaitu $9 \%$ hal ini berarti nilai protein dalam penelitian ini (semua perlakuan) memenuhi batasan protein menurut SNI 01-3818 tahun 1995.

\section{Kadar Lemak}

Hasil analisis sidik ragam kadar lemak pada bakso ayam petelur afkir menggunakan filler lokal dapat dilihat pada tabel 8. Hasil analisis sidik ragam menunjukkan bahwa penambah filler lokal masing-masing $25 \%$ tidak memberikan pengaruh nyata $(p>0.05)$ terhadap nilai lemak bakso petelur afkir. Dari hasil pengukuran lemak bakso ayam petelur afkir menunjukkan bahwa nilai rataan berkisar antara 2,59\%. Hasil pada penelitian ini lebih tinggi di banding penelitian Wirawan. et al, 2012 tentang penambahan pati biji durian terhadap kualitas bakso ayam yang kisarannya 2,1 $\%$. Menurut SNI standar ideal lemak bakso sebesar 2\%. Ini menunjukkan bahwa penambahan filler meningkatkan kadar lemak pada bakso ayam petelur akfir.

\section{Kadar Abu}

Hasil analisis kadar protein pada bakso ayam petelur afkir menggunakan filler lokal yang berbeda memberikan pengaruh yang nyata $(p<0.05)$ terhadap nilai abu bakso petelur afkir menggunakan filler lokal yang berbeda hal ini berarti bahwa penggunaan filler lokal yang berbeda dapat meningkatkan kadar abu bakso. Analisis lebih lanjut menggunakan uji BNJ menunjukkan bahwa perlakuan P1 menggunakan tepung sagu berbeda nyata terhadap P2 menggunakan tepung ubi kayu. Perlakuan P1 menggunakan tepung sagu berbeda nyata dengan perlakuan P3 menggunakan tepung talas. Perlakuan P2 menggunakan tepung ubi kayu berbeda nyata dengan perlakuan P3 menggunakan tepung talas.

Dari hasil pengukuran abu bakso ayam petelur afkir yang tercantum pada Tabel 8 menunjukkan bahwa nilai rataan abu bakso ayam petelur afkir menggunakan filler lokal yang berbeda berkisar antara 3,41\%. Nilai abu pada penelitian ini lebih tinggi bila dibanding dengan penelitian Herwin. et al, (2014) pengaruh subtitusi bubur labu kuning (cucurbita moschata) terhadap kualitas bakso ayam berkisar antara 1,38 \%. Nilai abu bakso menurut SNI maksimal 3\% hal ini berarti nilai protein dalam penelitian ini (semua perlakuan) mendekati batasan abu menurut Standar Nasional Indonesia 01-3818 tahun 1995.

\section{KESIMPULAN}

Berdasarkan hasil dan pembahasan dapat disimpulkan bahwa, Bahan filler lokal tidak berpengaruh nyata terhadap susut masak bakso akan tetapi berpengaruh nyata terhadap $\mathrm{pH}$ bakso, bahan filler lokal berpengaruh nyata 
terhadap kadar protein, dan abu bakso, namun tidak berpengaruh nyata terhadap kadar air, dan lemak bakso, bahan filler lokal tidak berpengaruh nyata terhadap aroma, tekstur, kekenyalan, dan rasa bakso namun berpengaruh nyata $(p<0,05)$ terhadap warna bakso dimana bakso dengan tepung sagu (P1) dan tepung ubi kayu (P2) lebih disukai oleh konsumen.

\section{DAFTAR PUSTAKA}

Buckle, K. A., A. Edwars, G. H. Fleet, M. Wootton. 2009. Ilmu Pangan. Terjemahan Purnomo, H. dan Adiono UI Press. Jakarta

Herwin V. Manurung Th. D.J. Tuju , L. C. Mandey, M. M. Ludong. 2014. Pengaruh subtitusi bubur labu kuning (cucurbita moschata) terhadap kualitas bakso ayam. Mahasiswa Program Studi Ilmu dan Teknologi Pangan Unsrat Dosen Ilmu dan Teknologi Pangan Unsrat. Fakultas Pertanian Universitas Sam Ratulangi Manado.

Idris, S. 2003. Indeks Efektivitas dalam Penentuan Perlakuan Terbaik. Fakultas Peternakan Universitas Brawijaya. Malang.

Rahmawaty, H \& W. Ma'aruf. 2006. Universitas Peternakan Universitas Samratulangi. Manado. Jurnal zootek, vol 23: 114-119 (Juli, 2006).
Siska, M. N. Lontaan , Sakul, S , A. Dp. Mirah. 2012. Sifat fisiko-kimia dan mutu organoleptik bakso broiler dengan menggunakan tepung ubi jalar (ipomoea batatas l) Fakultas Peternakan Universitas Sam Ratulangi Manado.

Tiven, N.C., E.Suryanto dan R'usman. 2007. Komposisi Kimia, Sifat Fisik, dan Organoleptik Bakso Daging ayam dengan Bahan Pengenyal yang Berbeda. Jurnal Agritech. 27 : $1-6$.

Kusnandar, F. 2010. Kimia Pangan : komponen makro. Dian Rakyat. Jakarta.

Saraswati, D. N, Rosyidi, D, And Widati, A, S. 2011. Substitusi Tepung Tapioka Dengan Pati Biji Nangka (Arthocarpus Heterophyllus Lamk) Terhadap Kualitas Fisik Bakso Daging Ayam. Universitas Brawijaya, Malang.

Wirawan, Y, Rosyidi, D, dan widyastuti, E, S. 2012. Pengaruh penambahan pati biji durian (durio zibethinus murr) terhadap kualitas kimia dan organoleptik bakso ayam. Universitas Brawijaya, Malang.

Prastya. A. S, Djalal Rosyidi, \& Imam. 2013. Subtitusi tepung tapioka dengan tepung sukun terhadap $\mathrm{pH}$, kadar air, kadar protein, kekerasan, dan susut masak bakso sapi. Universitas Brawijaya, Malang. 